\title{
Comparing adult height gain and menarcheal age between girls with central precocious puberty treated with gonadotropin-releasing hormone agonist alone and those treated with combined growth hormone therapy
}

Min Sub Kim, MD, Hyo Jung Koh, MD, Gwang Yeon Lee, MD, Dong Hee Kang, MD,

Se Young Kim, MD, PhD

Department of Pediatrics, Bundang Jesaeng General Hospital, Daejin Medical Center, Seongnam, Korea
Received: 27 August, 2018

Revised: 5 October, 2018

Accepted: 30 October, 2018

Address for correspondence:

Se Young Kim, MD, PhD

Department of Pediatrics, Bundang Jesaeng General Hospital Daejin Medical Center, Seongnam 13590, Korea

Tel: +82-31-779-0525

Fax: +82-31-779-0894

E-mail: odajulia@dmc.or.kr

https://orcid.org/0000-0003-49212795
Purpose: This study aimed to investigate the outcomes of gonadotropin-releasing hormone agonist $(\mathrm{GnRHa})$ therapy with or without growth hormone $(\mathrm{GH})$ therapy for girls with idiopathic central precocious puberty (CPP).

Methods: The medical records of 166 girls diagnosed with CPP from 2002 to 2017 were retrospectively reviewed. All included patients were treated with $\mathrm{GnRHa}$ for $\geq 36$ months. Changes in height standard deviation score (SDS) for bone age, chronological age (CA), and predicted adult height (PAH) were assessed for the first three years of treatment. The final height gain SDS was calculated as the difference between the initial PAH SDS and adult height (AH) SDS; these were then compared between the $\mathrm{GnRHa}$ group (group $\mathrm{A}, \mathrm{n}=135$ ) and the combined $\mathrm{GnRHa} / \mathrm{GH}$ group (group $\mathrm{B}, \mathrm{n}=31$ ).

Results: The initial mean CA was 7.89 years. The mean menarcheal age was 13.12 years (group $A, 13.1 \pm 0.99$; group $B, 13.18 \pm 0.58$ years; $P=0.755$ ). PAH SDS at the start of GnRHa treatment and AH SDS were significantly lower in group $B$ than in group A (PAH SDS: $-2.20 \pm 0.83$ vs. $-3.19 \pm 0.84, P<0.001$; AH SDS: $0.18 \pm 084$ vs. $-0.30 \pm 0.66$, $P=0.021)$. The increase in PAH SDS was higher in group $B$ than in group $A$ for the first three years of $\mathrm{GnRHa}$ treatment $(1.66 \pm 0.66$ vs. $2.35 \pm 0.93, P<0.001)$. The height gain SDS was significantly higher in group $B$ than in group $A$ ( $2.5 \pm 0.75$ vs. $2.93 \pm 1.02$, $P=0.048$ ). Younger age, higher $\mathrm{PAH}$ at the start of treatment, and a greater increase in PAH SDS during the first year of GnRHa treatment positively affected $\mathrm{AH}$.

Conclusion: The combined GH group had more additional height gain than the GnRHa-alone group.

Keywords: Puberty, Precocious, Gonadotropin-releasing hormone, Growth hormone, Body Height

\section{Introduction}

Patients with precocious puberty (PP) develop pubertal sex characteristics due to early activation of the hypothalamic-pituitary-gonadal (HPG) axis before the age of 8 years in girls and 9 years in boys. Premature pulsatile secretion of gonadotropin-releasing hormone (GnRH) leads to the release of luteinizing hormone (LH) and follicle-stimulating hormone, and these hormones subsequently stimulate the synthesis and secretion of estradiol (E2). This results in increased serum insulin-like growth factor-1 (IGF-1) levels. ${ }^{1,2)}$ This series of hormonal changes accelerates the maturation of bones, which may lead to a shorter height when the 
patient is an adult. The incidence of PP has been reported to be approximately 1:5000-1:10,000, and it is 10 times more common in girls than in boys. ${ }^{3)}$ In most cases the abnormal functioning of the HPG axis is idiopathic, although in rare cases intrasellar neoplasm, hematoma, hydrocephalus, brain injury, or hypothyroidism can be the cause. ${ }^{4,5}$ These are often termed "true" and "pseudo" PP, respectively, or central PP (CPP) and peripheral PP, respectively.

To prevent potential social maladjustment of the patients, it is necessary to minimize the early development of sexual characteristics and height loss. Thus, the use of GnRH agonists (GnRHas) has been a common treatment for CPP for more than 30 years since the use of leuprolide acetate was reported in $1981^{7)}$ and $1989 .{ }^{8)}$ Administration of GnRHas interferes with the pituitary-gonadal axis and reduces E2 release from the ovaries." It also leads to reduced growth velocity (GV), inhibited bone growth, and suspended or decreased development of secondary sex characteristics. ${ }^{5)}$ Consequently, GnRHa treatment is helpful in postponing pubertal development and retaining height potential. Several studies have demonstrated the efficacy of GnRHa treatment including improved final adult height (AH), especially in patients younger than 6 years of age. ${ }^{6,10-15)}$ However, other studies have reported that GnRHa treatment decreases active IGF-1s levels leading to relatively small gain in $\mathrm{AH} .{ }^{16-}$

${ }^{18)}$ In these cases, it would be reasonable to compensate for the reduction in IGF-1 levels during GnRHa therapy by combining growth hormone $(\mathrm{GH})$ with the GnRHa treatment. ${ }^{19-21)}$

The aim of this study was to compare the final outcomes of patients treated with GnRHa therapy with and without combined GH treatment. This included detailed evaluations performed during the three years after the initiation of GnRHa treatment and an investigation of factors that could have affected stature outcome.

\section{Materials and methods}

\section{Subjects}

We performed retrospective reviews of medical records from the Pediatric Department of Bundang Jesaeng General Hospital, Daejin Medical Center, Korea, from January 2002 to December 2016. Of the 1,636 patients who were diagnosed with CPP, 166 girls with CPP who were treated with GnRHa for $\geq 36$ months were selected. The patients were divided into 2 groups: those who received GnRHa alone (group A, n=135) and those who received GnRHa combined with GH (group $\mathrm{B}, \mathrm{n}=31$ ) (Fig. 1). $\mathrm{AH}$ and menarche data were available for 86 subjects. Thus, all statistics, including $\mathrm{AH}$ and menarche, were performed with 86 subjects (group A, $\mathrm{n}=66$ ). The classical diagnostic criteria for idiopathic CPP were an age of 8 years or less at breast development (i.e., Tanner stage B2 or above), bone age (BA) advancement (i.e., at least 1 year more than chronological age [CA]), a peak LH level determined with electrochemiluminescence immunoassays above 5 IU/L during a standard GnRH-stimulation test, and no evidence of organic lesions on the hypothalamic-pituitary axis confirmed using magnetic resonance imaging scans. Patients who had other conditions, such as thyroid disease, genetic impairment, and ovarian or adrenal diseases, were excluded. Patients who had abnormal androgen release and congenital adrenal hypertrophy were also excluded from the analysis of serum 17-hydroxyprogesterone and delta 4-dehydioepiadrostendione sulfate levels. GH was given to patient who either fell below the fifth percentile for predicted adult height $(\mathrm{PAH})$ at the time of diagnosis, fell below the fifth percentile for midparental height $(\mathrm{MPH})$, or had a slow $\mathrm{GV}$ of under $5 \mathrm{~cm}$ per year.

\section{Methods}

All patients were administered GnRHa at a dose of 60-90 $\mu \mathrm{g} /$ kg every 4 weeks. In group B, patients were additionally treated with GH at a dose of $0.25 \mathrm{mg} / \mathrm{kg}$ every week. Height, weight, and pubertal advancements were recorded for all patients every 4 weeks after the first visit. The BA was recorded every 6 months. Data collected at the beginning of the GnRHa treatment, at 1,2, and 3 years after the initial treatment, and at the end of GnRHa treatment was used in this analysis. Height was measured to the nearest $0.1 \mathrm{~cm}$ using a Harpenden Stadiometer (Holtain Ltd., Crymych. UK). BA was assessed using the Greulich-Pyle method $^{22)}$ by the same observer using anteroposterior view films of the left wrist. MPH was defined as the average of the parental heights minus $6.5 \mathrm{~cm}$. PAH was calculated using the average Bayley-Pinneau method. ${ }^{23)}$ Annual changes in height were assessed and expressed as a standard deviation score (SDS) for CA and BA using the 2017 Korean National Growth Charts. ${ }^{24)} \mathrm{PAH}, \mathrm{MPH}$ and AH were also expressed as SDSs for the purpose of comparing them. We made inquiries regarding AH for patients who had grown less than $1 \mathrm{~cm}$ a year, were at least 2 years past their menarcheal age, and who had a BA over 15 years. AH was collected via telephone interviews, and

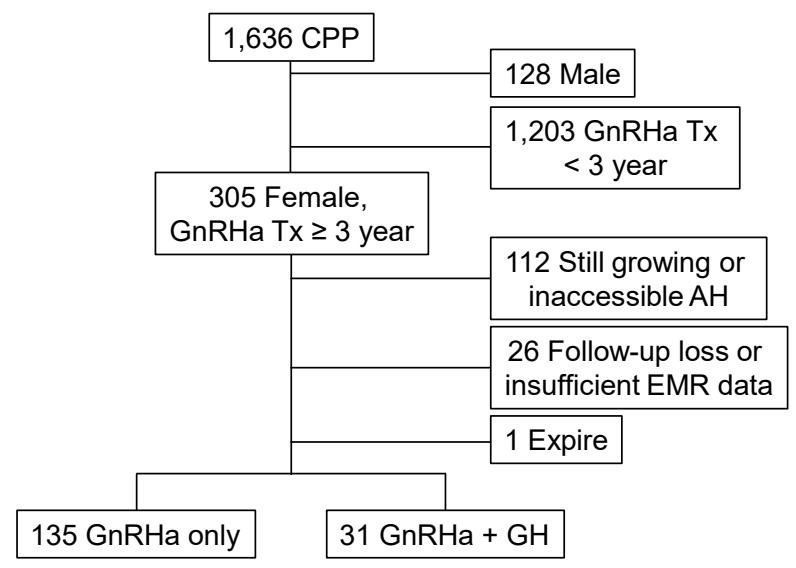

Fig. 1. Trail design schematic. CPP, central precocious puberty; GnRHa, gonadotropin-releasing hormone agonist; $T \mathrm{~T}$, treatment; $\mathrm{AH}$, adult height; $\mathrm{EMR}$, electronic medical record; GH, growth hormone. 
height and BA were confirmed in the outpatient clinics. The menarcheal age of these 86 girls was also reported by patients. To demonstrate the effectiveness of the treatment, we evaluated the differences between the SDSs for AH and initial PAH, for $\mathrm{AH}$ and $\mathrm{MPH}$, and for $\mathrm{AH}$ and initial height.

Blood chemistry parameters, such as thyroid stimulating hormone, free thyroxine, E2, total estrogen, LH, IGF-1, and IGF-binding protein 3 (IGF-BP3), were measured using a Hitachi Automatic Immunology Analyzer (Cobas E170, Roche, Rotkreuz, Switzerland) at the initial diagnosis and the end of the GnRHa treatment.

\section{Statistical analysis}

The IBM SPSS Statistics ver. 24.0 (IBM Co., Armonk, NY, USA) was used for the statistical analyses of the data. All data are expressed as the mean \pm standard deviation. The paired $t$-test was applied to compare data within each group, and the independent $t$-test was used to make comparisons between the 2 groups. Multiple linear regression analysis was used to determine correlations between multiple parameters and height outcome. A $P$-value of $<0.05$ was considered statistically significant.

\section{Results}

\section{Characteristics and auxological data}

The mean CA and BA of patients at the beginning of GnRHa treatment were $7.89 \pm 0.81$ and $9.67 \pm 0.91$ years, respectively. The BA was $1.78 \pm 0.70$ years more than the $\mathrm{CA}$ at the start of $\mathrm{GnRHa}$ treatment. All patients were treated with GnRHa for $45.25 \pm 8.45$ months. Patients in group B were treated for longer than those in group $\mathrm{A}(P=0.017)$. The mean duration of $\mathrm{GH}$ treatment was $39.23 \pm 16.94$ months. After the initiation of GnRHa treatment, it was a mean of 19.19 months before GH treatment was started. The initial height of patients was $128.17 \pm 0.7 \mathrm{~cm}$, and the PAH was $149.96 \pm 4.03 \mathrm{~cm}$. The patients in group B had a lower initial height and PAH $(P<0.001$ for both $)$. The height at the end of the treatment was $148.99 \pm 4.27 \mathrm{~cm}$ and $148.62 \pm 3.67 \mathrm{~cm}$ for groups $\mathrm{A}$ and $\mathrm{B}$, respectively; however, this was not significantly different. The BA, $\triangle \mathrm{BA}-\mathrm{CA}$, and $\mathrm{PAH}$ were significantly different between groups $A$ and $B$ at the start of the treatment, but there was no statistically significant differences between the 2 groups at the end of GnRHa treatment. The MPH, as the target height, and the $\mathrm{AH}$ of the patients in group A were higher than in group $\mathrm{B}(\mathrm{MPH} ; \mathrm{P}<0.001, \mathrm{AH} ; \mathrm{P}=0.02)$. The mean menarcheal age was 13.12 years. The time between menarche and the end date of GnRHa therapy was not statistically significantly different between the 2 groups (Table 1). There were no statistically significant differences between the 2 groups for other biochemical laboratory tests, including IGF-1 and IGF-BP3, at start of GnRHa treatment (Table 2).
Table 1. Auxological data of the subjects with CPP $(n=166)$ divided into 2 groups by type of treatment

\begin{tabular}{|c|c|c|c|}
\hline Variable & $\begin{array}{l}\text { Group A } \\
(n=135)\end{array}$ & $\begin{array}{l}\text { Group B } \\
(n=31)\end{array}$ & $P$-value \\
\hline \multicolumn{4}{|l|}{ At start of GnRHa } \\
\hline $\mathrm{CA}(\mathrm{yr})$ & $7.91 \pm 0.77$ & $7.81 \pm 0.97$ & $<0.001$ \\
\hline$B A(y r)$ & $9.77 \pm 0.84$ & $9.25 \pm 1.10$ & 0.004 \\
\hline $\mathrm{BA}-\mathrm{CA}(\mathrm{yr})$ & $1.86 \pm 0.68$ & $1.44 \pm 0.70$ & 0.002 \\
\hline Height SDSC & $0.61 \pm 0.89$ & $-0.47 \pm 0.75$ & $<0.001$ \\
\hline Height SDSb & $-1.45 \pm 0.88$ & $-2.07 \pm 0.76$ & $<0.001$ \\
\hline Weight SDS & $0.58 \pm 0.84$ & $-0.22 \pm 0.85$ & $<0.001$ \\
\hline BMI SDS & $0.39 \pm 0.91$ & $0.06 \pm 1.15$ & 0.084 \\
\hline MPHSDS & $-0.38 \pm 0.72$ & $-0.93 \pm 0.71$ & $<0.001$ \\
\hline $\mathrm{PAH}(\mathrm{cm})$ & $150.76 \pm 3.69$ & $146.44 \pm 3.56$ & $<0.001$ \\
\hline PAHSDS & $-2.20 \pm 0.83$ & $-3.19 \pm 0.84$ & $<0.001$ \\
\hline \multicolumn{4}{|l|}{ At 1 year after GnRHa start } \\
\hline $\mathrm{BA}(\mathrm{yr})$ & $10.35 \pm 0.67$ & $9.91 \pm 0.97$ & 0.003 \\
\hline BA-CA (yr) & $1.44 \pm 0.71$ & $1.12 \pm 0.68$ & 0.023 \\
\hline Height SDSC & $0.61 \pm 0.89$ & $-0.47 \pm 0.75$ & $<0.001$ \\
\hline Height SDSb & $-1.45 \pm 0.88$ & $-2.07 \pm 0.76$ & $<0.001$ \\
\hline $\mathrm{PAH}(\mathrm{cm})$ & $153.64 \pm 3.76$ & $150.26 \pm 3.43$ & $<0.001$ \\
\hline PAH SDS & $-1.57 \pm 0.82$ & $-2.31 \pm 0.78$ & $<0.001$ \\
\hline \multicolumn{4}{|l|}{ At 3 year after GnRHa start } \\
\hline $\mathrm{BA}(\mathrm{yr})$ & $11.52 \pm 0.59$ & $11.03 \pm 0.74$ & $<0.001$ \\
\hline$B A-C A(y r)$ & $0.61 \pm 0.70$ & $0.26 \pm 0.66$ & 0.011 \\
\hline Height SDSC & $-0.14 \pm 0.89$ & $-0.33 \pm 0.78$ & 0.008 \\
\hline Height SDSb & $-0.46 \pm 0.77$ & $-0.59 \pm 0.76$ & 0.386 \\
\hline $\mathrm{PAH}(\mathrm{cm})$ & $158.46 \pm 4.15$ & $157.03 \pm 4.18$ & 0.086 \\
\hline PAH SDS & $-0.55 \pm 0.87$ & $-0.85 \pm 0.90$ & 0.088 \\
\hline \multicolumn{4}{|l|}{ At end of $\mathrm{GnRHa}$} \\
\hline$C A(y r)$ & $11.56 \pm 0.62$ & $11.90 \pm 0.60$ & 0.006 \\
\hline$B A(y r)$ & $11.83 \pm 0.51$ & $11.71 \pm 0.52$ & 0.247 \\
\hline $\mathrm{BA}-\mathrm{CA}(\mathrm{yr})$ & $0.18 \pm 1.05$ & $-0.19 \pm 0.47$ & 0.055 \\
\hline Height SDSC & $-0.002 \pm 0.91$ & $-0.37 \pm 0.75$ & 0.038 \\
\hline Height SDSb & $-0.24 \pm 0.68$ & $-0.21 \pm 0.67$ & 0.783 \\
\hline PAH $(\mathrm{cm})$ & $160.09 \pm 3.88$ & $160 \pm 3.52$ & 0.906 \\
\hline PAH SDS & $-0.21 \pm 0.79$ & $-0.23 \pm 0.72$ & 0.921 \\
\hline \multicolumn{4}{|l|}{ Duration of treatment } \\
\hline GnRHa (mo) & $44.25 \pm 7.33$ & $49.58 \pm 11.35$ & 0.017 \\
\hline $\mathrm{GH}(\mathrm{mo})$ & - & $39.23 \pm 16.94$ & \\
\hline $\begin{array}{l}\text { Starting time of GH after } \\
\text { GnRHa (mo) }\end{array}$ & - & $19.19 \pm 19.48$ & \\
\hline \multicolumn{4}{|l|}{ At menarche } \\
\hline CA (yr) & $13.10 \pm 0.99$ & $13.17 \pm 0.58$ & 0.755 \\
\hline After the end of GnRHa (mo) & $18.58 \pm 8.27$ & $14.81 \pm 6.24$ & 0.075 \\
\hline
\end{tabular}

Values are presented as the mean \pm standard deviation.

Group A, GnRHa alone group; group B, combined GnRHa/GH group; CPP, central precocious puberty; GnRHa, gonadotropinreleasing hormone agonist; $C A$, chronological age; $B A$, bone age; BMI, body mass index; SDS, standard deviation score; SDSC, standard deviation score for chronologic age; SDSb, standard deviation score for bone age; $\mathrm{PAH}$, predicted adult height; $\mathrm{MPH}$, midparental height; $A H$, adult height; $\triangle H G$, difference between AH SDS and PAH SDS at start of GnRHa treatment. 
Table 1. Auxological data of the subjects with CPP ( $n=166)$ divided into 2 groups by type of treatment (continued)

\begin{tabular}{|c|c|c|c|}
\hline Variable & $\begin{array}{l}\text { Group A } \\
(n=135)\end{array}$ & $\begin{array}{c}\text { Group B } \\
(n=31)\end{array}$ & $P$-value \\
\hline \multicolumn{4}{|l|}{ Assessment of outcome } \\
\hline$\triangle \mathrm{PAH}$ SDS 0-3 & $1.66 \pm 0.65$ & $2.35 \pm 0.93$ & $<0.001$ \\
\hline $\mathrm{AH}(\mathrm{cm})$ & $162.03 \pm 4.19$ & $159.62 \pm 3.22$ & 0.02 \\
\hline AHSDS & $0.18 \pm 0.84$ & $-0.30 \pm 0.66$ & 0.021 \\
\hline $\mathrm{AH}-\mathrm{MPH}(\mathrm{cm})$ & $2.80 \pm 4.16$ & $3.24 \pm 2.93$ & 0.657 \\
\hline AH SDS - MPH SDS & $0.56 \pm 0.83$ & $0.68 \pm 0.61$ & 0.567 \\
\hline $\mathrm{AH}-\mathrm{PAH}$ at start $(\mathrm{cm})$ & $11.81 \pm 3.62$ & $13.35 \pm 4.62$ & 0.124 \\
\hline $\begin{array}{l}\text { AH SDS - PAH SDS at start } \\
(\triangle H G)\end{array}$ & $2.50 \pm 0.75$ & $2.93 \pm 1.02$ & 0.048 \\
\hline AH SDS - Height SDSb at & $1.86 \pm 0.72$ & $1.74 \pm 0.92$ & 0.542 \\
\hline
\end{tabular}

start

Values are presented as the mean \pm standard deviation.

Group A, GnRHa alone group; group B, combined GnRHa/GH group; CPP, central precocious puberty; GnRHa, gonadotropinreleasing hormone agonist; SDS, standard deviation score; SDSb, standard deviation score for bone age; $\mathrm{PAH}$, predicted adult height; $\mathrm{MPH}$, midparental height; $\mathrm{AH}$, adult height; $\triangle \mathrm{HG}$, difference between AH SDS and PAH SDS at start of GnRHa treatment.

\section{Comparison of growth outcomes during first three years of GnRHa treatment}

The increase in PAH SDS from the beginning of GnRHa treatment to the third year ( $\triangle \mathrm{PAH}$ SDS $0-3)$ was significantly higher in group $\mathrm{B}$ than in group $\mathrm{A}(P<0.001)$. The increase in height SDS for BA (SDSb) and CA (SDSc) from the start to the third year of GnRHa treatment were also statistically higher in group B ( $P<0.001$ for both) (Table 1; Figs. 2, 3). The PAH SDS,

Table 2. Laboratory data of the subjects with CPP $(n=166)$ divided into 2 groups by type of treatment

\begin{tabular}{lccc}
\hline At start of GnRHa & Group A $(n=135)$ & Group B $(n=31)$ & $P$-value \\
\hline Total E & $73.14 \pm 50.85$ & $66.63 \pm 61.40$ & 0.216 \\
Peak LH & $12.10 \pm 11.89$ & $9.17 \pm 5.89$ & 0.051 \\
IGF-1 & $301.89 \pm 95.76$ & $288.86 \pm 111.14$ & 0.157 \\
IGF-BP3 & $3,247.56 \pm 804.34$ & $3,246.83 \pm 699.80$ & 0.997 \\
IGF-1/IGF-BP3 & $0.10 \pm 0.03$ & $0.09 \pm 0.03$ & 0.276 \\
\hline
\end{tabular}

Values are presented as the mean \pm standard deviation.

Group A, GnRHa alone group; group B, combined GnRHa/GH group; CPP, central precocious puberty; GnRHa, gonadotropinreleasing hormone agonist; $\mathrm{E}$, estrogen; $\mathrm{LH}$, luteinizing hormone; IGF-1, insulin-like growth factor-1; IGF-BP3, insulin-like growth factor binding protein 3.
(A)

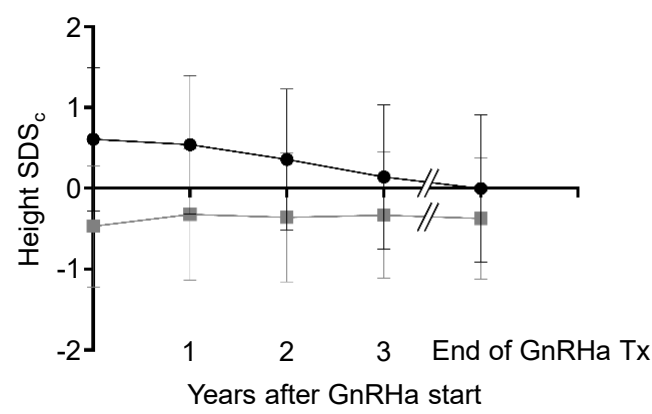

(C)

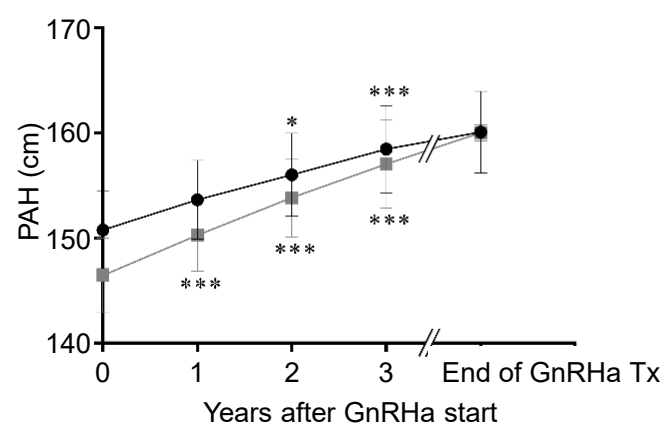

(B)

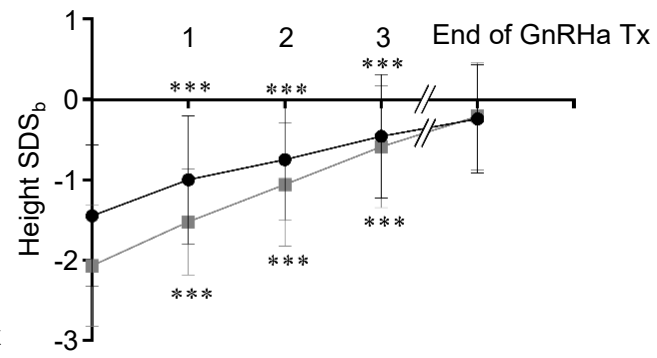

(D) Years after GnRHa start

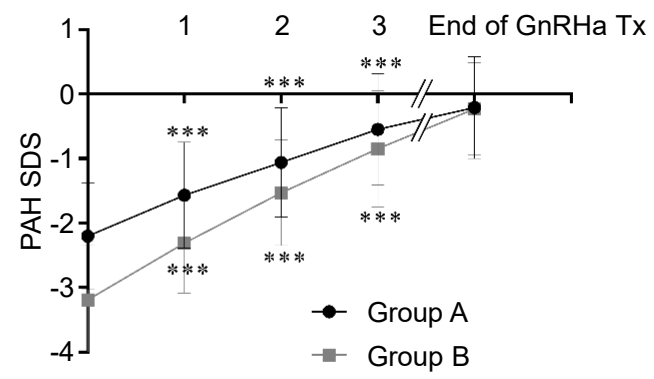

Fig. 2. Changes in height SDSC (A), height SDSb (B), PAH (C), and PAH SDS (D) of subjects with CPP by type of treatment (black, group A; grey, group B). Group A, GnRHa alone group; group B, combined GnRHa/GH group; SDS, standard deviation score; SDSC, standard deviation score for chronological age; SDSb, standard deviation score for bone age; GnRHa, gonadotropin-releasing hormone agonist; $\mathrm{PAH}$, predicted adult height; TX, treatment. ${ }^{*} P<0.05$ vs. 1 year ago. ${ }^{* * *} P<0.001$ vs. 1 year ago. 
height SDSb, and height SDSc significantly increased at the end of GnRHa treatment $(P<0.001$ for all), and the increases were greater in group $\mathrm{B}(P<0.001$ for all $)$.

\section{Comparison of $\mathrm{AH}$ growth outcome}

In terms of therapeutic effects, the $\mathrm{AH}(161.47 \pm 4.10 \mathrm{~cm})$ was over the target height $(158.75 \pm 3.63 \mathrm{~cm})$ and significantly higher than the initial PAH in each group $(P<0.001)$. The AH SDS was also significantly greater than the initial PAH SDS and $\mathrm{MPH}$ SDS in each group $(P<0.001)$ (Fig. 3$)$. The height gain $(\Delta H G)$, which is the difference between the AH SDS and the initial PAH SDS, was significantly higher in group $\mathrm{B}$, although the difference between $\mathrm{AH}$ and initial PAH was not statistically significant (Table 1). Also, HG calculated as the difference between AH SDS and initial height SDSb was not significantly different between the 2 groups.

\section{Correlation between $\mathrm{AH}$ and other auxological factors}

Multiple regression analysis was used to identify factors influencing $\mathrm{AH}$ (Table 3). Only the patients from group A were used in this analysis; those in group $B$ were excluded because $\mathrm{GH}$ treatment could be a confounding factor. A younger initial $\mathrm{CA}$, a higher initial PAH SDS, and a greater increase in PAH SDS 1 year after the start of GnRHa treatment were significantly positively correlated with AH (Table1, Fig. 2). The BA at the start of treatment, MPH SDS, and the duration of the GnRHa treatment did not correlate with $\mathrm{AH}$.

\section{Menarcheal age}

Menarche occurred at $13.12 \pm 0.92$ years of age, and there were no statistically significant differences between the 2 groups $(P=0.775)$ (Table 1). The duration from the end of GnRHa treatment to menarche was $17.80 \pm 8.02$ months, but there was no significant difference observed between the groups $(P=0.075)$.

Table 3. Multiple linear regression analysis on $\mathrm{AH}(\mathrm{n}=66$, $\left.R^{2}=0.535, P<0.001\right)$

\begin{tabular}{lccc}
\hline Variable & $\beta$ & SE & $P$-value \\
\hline CA at start & -2.443 & 0.728 & 0.001 \\
BA at start & 1.388 & 0.740 & 0.066 \\
MPH SDS & 1.205 & 0.651 & 0.069 \\
PAH SDS at start & 3.601 & 0.623 & $<0.001$ \\
$\triangle$ PAH SDS for first year & 3.205 & 1.048 & 0.003 \\
Duration of GnRHa treatment & -0.064 & 0.072 & 0.375
\end{tabular}

$\mathrm{AH}$, adult height; $\mathrm{SE}$, standard error; $\mathrm{CA}$, chronological age; $\mathrm{BA}$, bone age; MPH, midparental height; SDS, standard deviation score; $\mathrm{PAH}$, predicted adult height; $\triangle$, difference; GnRHa, gonadotropin-releasing hormone agonist.
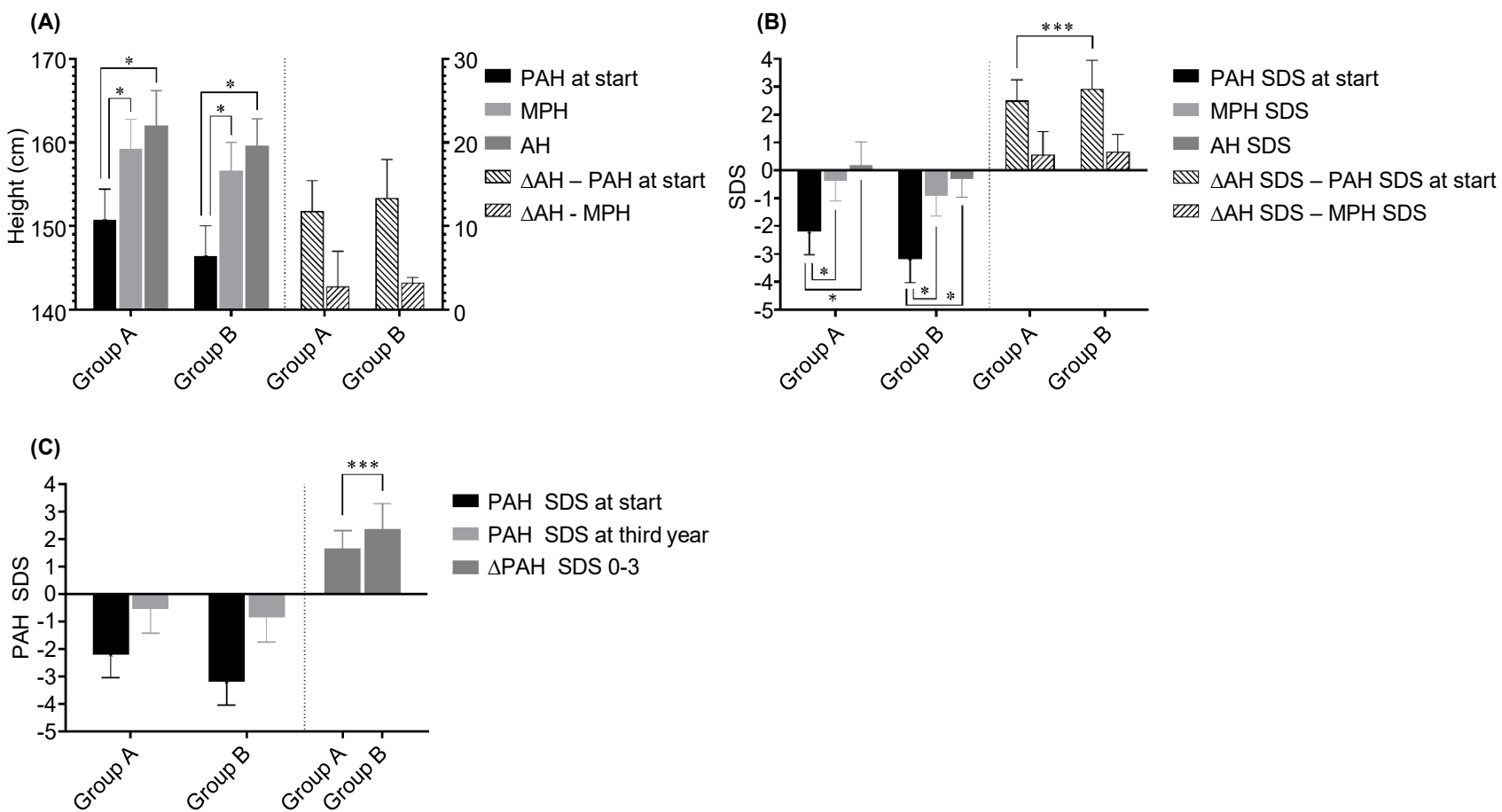

Fig. 3. Comparison of PAH, MPH, AH, and changes in subjects with central precocious puberty by type of treatment, expressed as (A) height, (B) SDS, and (C) PAH SDS for the first 3 years of gonadotropin-releasing hormone agonist (GnRHa) treatment. Group A, GnRHa alone group; group B, combined GnRHa/GH group; PAH, predicted adult height; MPH, midparental height; AH, adult height; SDS, standard deviation score. " $P<0.001$ vs. PAH or PAH SDS at start of GnRHa treatment. ${ }^{{ }^{* * *}} P<0.001$ between the GnRHa group and the GnRHa plus GH group. 


\section{Discussion}

We performed a retrospective review of 166 patients with CPP who were treated with GnRHa either in combination with GH or without for more than 3 years and evaluated the longterm effects.

For the first 3 years overall of GnRHa treatment, the increase in PAH SDS was significantly higher in group B. However, the annual increase in PAH SDS was higher in group B than in group A for each of the first 2 years, but there was not a clear difference in the third year (first year, $P=0.02$; second year, $P=0.008$; and third year, $P=0.108$ ) (Fig. 2). The AH SDS was significantly higher than the PAH SDS at the start of GnRHa treatment in both groups. The increase in height gain in group $\mathrm{B}$ was 2.93 SDS, which was a greater increase compared to group A (approximately 2.5 SDS). In addition, a younger CA, higher PAH SDS, and greater increase in PAH SDS in the first year were correlated to a greater increase in $\mathrm{AH}$.

In 1991, Oostdijk et al. ${ }^{25)}$ reported that combined GnRHa/ GH treatment improved PAH in three girls with CPP who had a low GV when treated with GnRHa alone. Subsequent studies have also described better outcomes for girls treated with combination therapy, ${ }^{20,26-30)}$ and some Korean reports have also been published. ${ }^{31,32)}$ Volta et al. ${ }^{33)}$ highlighted that the combined treatment could be helpful for CPP patients with slow growth. Jung et al. ${ }^{31)}$ found a greater difference between $\mathrm{AH}$ and $\mathrm{PAH}$ at the beginning of treatment in the GnRHa plus GH group compared to the GnRHa-alone group, but this was not a significant statistical difference. Gyon et al. ${ }^{32)}$ reported that the combined treatment group had a significantly higher increase in height from PAH at the start to near final height (NFH) $(P<0.001)$. These results are similar to the present report. Those 2 Korean studies also evaluated factors that positively influence AH SDS and NFH. In the study of Jung et al., ${ }^{31)}$ younger CA and taller MPH were factors, and in the study of Gyon et al., ${ }^{32)}$ taller height at the start, taller MPH, and longer treatment duration were factors. These previous results are partially in line with present study. The menarcheal age in this study was $13.12 \pm 0.92$ years and older than the study of Gyon et al. ${ }^{32)}$ at $11.6 \pm 0.8$ years. The time from the end of GnRHa treatment to menarche was $17.80 \pm 8.02$ months in this study, which was longer than the $15.7 \pm 6.4$ months in Gyon et al. ${ }^{32)}$ or the $1.0 \pm 0.61$ years in Jung et al. ${ }^{31)}$ This could be the result of the inclusion criteria for this study of GnRHa treatment of 36 months or more.

To our knowledge, our study is the largest retrospective, single-center study that compared statural outcomes in girls with CPP after treatment with GnRHa alone or GnRHa plus GH. In addition, our study was strictly controlled for more than three years of GnRHa treatment for all patients.

The limitations of our study are as follows: (1) PAH SDS, height SDS, and MPH SDS at the start of treatment were significantly lower in the GnRHa plus GH group. This indicates that the subjects were not sufficiently randomized for both therapies, possibly due to a selection bias. (2) The results might be influenced by the differences in the duration of GnRHa treatment. Furthermore, in the GnRHa plus GH group, it is difficult to determine whether the higher $\triangle H G$ was due to the addition of GH or the longer duration of GnRHa therapy. Thus, we compared the change of PAH SDS for the first 3 years of GnRHa treatment between the two groups, which indicated that additional GH administration caused the greater increase in HG. (3) In our study, there was a statistically significant difference between the 2 groups for $\Delta \mathrm{HG}(P=0.048)$, but $\mathrm{AH}$ $\mathrm{PAH}$ at the start was not significantly different $(P=0.124)$ (Table $1)$. This is relatively weak evidence compared with the previous report by Gyon et al. ${ }^{32)}(P<0.001)$. (4) We used the BayleyPinneau method with average tables to estimate PAH at the start of GnRHa treatment, which can relatively underestimate PAH compared with the other table, thus affecting the presented height gain. (5) We used the 2017 Korean National Growth Chart as a reference. However, some of the subjects were treated according to the 2007 Korean National Growth Chart or the growth standard index available at the time of treatment, which might be different from the SDS value considered for treatment and the SDS value shown in this study. However, the 2017 growth standard index was used consistently in this study; therefore, the comparisons between the subjects are believed to be reliable. However, more rigorous randomized controlled studies will be needed in the future.

In conclusion, GnRHa treatment increased adult height in girls with CPP, and GnRHa plus GH therapy can lead to a greater final height than GnRHa-alone therapy. Also, the increase in PAH SDS during the first year of GnRHa treatment can be a predictive tool to estimate therapy effectiveness.

\section{Ethical statement}

This study was approved by the Institutional Review Board (IRB) of Bundang Jesaeng General Hospital (IRB No. PD18-01), and an exemption was made for the requirement of informed consent.

\section{Conflict of interest}

No potential conflict of interest relevant to this article was reported.

\section{References}

1. Partsch CJ, Sippell WG. Pathogenesis and epidemiology of precocious puberty. Effects of exogenous oestrogens. Hum Reprod Update 2001;7:292-302.

2. Su PH, Wang SL, Chen JY, Chen SJ, Ke JC. A study of anthropomorphic and biochemical characteristics in girls with central precocious puberty and thelarche variant. J Pediatr Endocrinol Metab 2008;21:213-20.

3. Cesario SK, Hughes LA. Precocious puberty: a comprehensive review of literature. J Obstet Gynecol Neonatal Nurs 2007;36:263-74. 
4. Chauhan A, Grissom M. Disorders of childhood growth and development: precocious puberty. FP Essent 2013;410:25-31.

5. Carel JC, Eugster EA, Rogol A, Ghizzoni L, Palmert MR; ESPE-LWPES GnRH Analogs Consensus Conference Group, et al. Consensus statement on the use of gonadotropin-releasing hormone analogs in children. Pediatrics 2009;123:e752-62.

6. Partsch CJ, Heger S, Sippell WG. Management and outcome of central precocious puberty. Clin Endocrinol (Oxf) 2002;56:129-48.

7. Crowley WF Jr, Comite F, Vale W, Rivier J, Loriaux DL, Cutler GB Jr. Therapeutic use of pituitary desensitization with a long-acting lhrh agonist: a potential new treatment for idiopathic precocious puberty. J Clin Endocrinol Metab 1981;52:370-2.

8. Parker KL, Lee PA. Depot leuprolide acetate for treatment of precocious puberty. J Clin Endocrinol Metab 1989;69:689-91.

9. Allali S, Lemaire P, Couto-Silva AC, Prété G, Trivin C, Brauner R. Predicting the adult height of girls with central precocious puberty. Med Sci Monit 2011;17:PH41-8.

10. Clemons RD, Kappy MS, Stuart TE, Perelman AH, Hoekstra FT. Long-term effectiveness of depot gonadotropinreleasing hormone analogue in the treatment of children with central precocious puberty. Am J Dis Child 1993;147:653-7.

11. Kauli R, Galatzer A, Kornreich L, Lazar L, Pertzelan A, Laron Z. Final height of girls with central precocious puberty, untreated versus treated with cyproterone acetate or GnRH analogue. A comparative study with re-evaluation of predictions by the Bayley-Pinneau method. Horm Res 1997;47:54-61.

12. Lanes R, Soros A, Jakubowicz S. Accelerated versus slowly progressive forms of puberty in girls with precocious and early puberty. Gonadotropin suppressive effect and final height obtained with two different analogs. J Pediatr Endocrinol Metab 2004;17:759-66.

13. Léger J, Reynaud R, Czernichow P. Do all girls with apparent idiopathic precocious puberty require gonadotropin-releasing hormone agonist treatment? J Pediatr 2000;137:819-25.

14. Lee PA, Neely EK, Fuqua J, Yang D, Larsen LM, MattiaGoldberg C, et al. Efficacy of leuprolide acetate 1-month depot for central precocious puberty (CPP): growth outcomes during a prospective, longitudinal study. Int J Pediatr Endocrinol 2011;2011:7.

15. Kwon EB, Lee SJ, Cha M, Kim SY. Changes in the predicted adult height after gonadotropin-releasing hormone agonist treatment in girls with idiopathic true precocious puberty. Ann Pediatr Endocrinol Metab 2012;17:160-8.

16. Müller J, Juul A, Andersson AM, Sehested A, Skakkebaek NE. Hormonal changes during GnRH analogue therapy in children with central precocious puberty. J Pediatr Endocrinol Metab 2000;13 Suppl 1:739-46.
17. Wu JM, Yu J, Yang Y. Gene expression related to growth axis and gonadal axis in puberty rats. Zhong Xi Yi Jie He Xue Bao 2003;1:35-8.

18. Cara JF, Burstein S, Cuttler L, Moll GW Jr, Rosenfield RL. Growth hormone deficiency impedes the rise in plasma insulin-like growth factor I levels associated with precocious puberty. J Pediatr 1989;115:64-8.

19. Pasquino AM, Municchi G, Pucarelli I, Segni M, Mancini MA, Troiani S. Combined treatment with gonadotropinreleasing hormone analog and growth hormone in central precocious puberty. J Clin Endocrinol Metab 1996;81:94851.

20. Pasquino AM, Pucarelli I, Segni M, Matrunola M, Cerroni F. Adult height in girls with central precocious puberty treated with gonadotropin-releasing hormone analogues and growth hormone. J Clin Endocrinol Metab 1999;84:449-52.

21. Kohn B, Julius JR, Blethen SL. Combined use of growth hormone and gonadotropin-releasing hormone analogues: the national cooperative growth study experience. Pediatrics 1999;104(4 Pt 2):1014-8.

22. Pyle SI, Greulich WW. Radiographic atlas of skeletal development of the hand and wrist. Stanford: Stanford University Press, 1959.

23. Bayley N, Pinneau SR. Tables for predicting adult height from skeletal age: revised for use with the Greulich-Pyle hand standards. J Pediatr 1952;40:423-41.

24. Korea Centers for Disease Control and Prevention (KCDC); Korean Pediatric Society, Committee for the Development of Growth Standard or Korean Children and Adolescents. 2017 Korean children and adolescents growth standard: commentary for the development of 2017 growth chart [Internet]. Cheongwon: KCDC, Division of Chronic Disease Surveillance; c2018 [cited 2018 May 11]. Available from: http:// www.cdc.go.kr/CDC/contents/CdcKrContentView. jsp?cid =77683\&menuIds=HOME001-MNU1130MNU2743-MNU2748-MNU2744.

25. Oostdijk W, Drop SL, Odink RJ, Hümmelink R, Partsch CJ, Sippell WG. Long-term results with a slow-release gonadotrophin-releasing hormone agonist in central precocious puberty. Dutch-German Precocious Puberty Study Group. Acta Paediatr Scand Suppl 1991;372:39-45.

26. Pucarelli I, Segni M, Ortore M, Arcadi E, Pasquino AM. Effects of combined gonadotropin-releasing hormone agonist and growth hormone therapy on adult height in precocious puberty: a further contribution. J Pediatr Endocrinol Metab 2003;16:1005-10.

27. Mul D, Oostdijk W, Waelkens JJ, Drop SL. Final height after treatment of early puberty in short adopted girls with gonadotrophin releasing hormone agonist with or without growth hormone. Clin Endocrinol (Oxf) 2005;63:185-90.

28. Saggese G, Pasquino AM, Bertelloni S, Baroncelli GI, Battini R, Pucarelli I, et al. Effect of combined treatment with gonadotropin releasing hormone analogue and growth hormone in patients with central precocious puberty 
who had subnormal growth velocity and impaired height prognosis. Acta Paediatr 1995;84:299-304.

29. Mul D, Oostdijk W, Waelkens JJ, Schulpen TW, Drop SL. Gonadotrophin releasing hormone agonist treatment with or without recombinant human GH in adopted children with early puberty. Clin Endocrinol (Oxf) 2001;55:121-9.

30. Tuvemo T, Gustafsson J, Proos LA. Growth hormone treatment during suppression of early puberty in adopted girls. Swedish Growth Hormone Advisory Group. Acta Paediatr 1999;88:928-32.

31. Jung MK, Song KC, Kwon AR, Chae HW, Kim DH, Kim HS. Adult height in girls with central precocious puberty treated with gonadotropin-releasing hormone agonist with or without growth hormone. Ann Pediatr Endocrinol Metab 2014;19:214-9.

32. Gyon Y, Yun YJ, Kim YD, Han HS. Age at menarche and near final height after treatment with gonadotropinreleasing hormone agonist alone or combined with growth hormone in Korean girls with central precocious puberty. Clin Pediatr Endocrinol 2015;24:175-83.

33. Volta C, Regazzi C, Ndaka J, Vitale R, Bernasconi S. Combined therapy with luteinizing hormone releasing hormone agonist (LHRHa) and growth hormone (GH) in central precocious puberty. Acta Biomed 2005;76:73-8. 